$$
\begin{aligned}
& \text { ANL/ER/CP- }-95272 \\
& \text { CONF-980307 }
\end{aligned}
$$

Experiment Close Out of Lysimeter Testing of Low-Level Radioactive Waste Forms

J. W. McConnell, Jr., R. D. Rogers, J. D. Jastrow,

S. R. Cline, T. M. Sullivan, and P. R. Reed

March 1-4, 1998

Waste Management '98 Conference, Tucson, Arizona

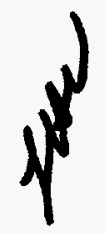

LOCKMEE D m A TIN T

DISTRIBUTION OF THIS DOCUMENT IS UNLMATED 


\section{DISCLAMER}

This report was prepared as an account of work sponsored by an agency of the United States Government. Neither the United States Government nor any agency thereof, nor any of their employees, makes any warranty, express or implied, or assumes any legal liability or responsibility for the accuracy, completeness, or usefulness of any information, apparatus, product, or process disclosed, or represents that its use would not infringe privately owned rights. Reference herein to any specific commercial product, process, or service by trade name, trademark, manufacturer, or otherwise does not necessarily constitute or imply its endorsement, recommendation, or favoring by the United States Government or any agency thereof. The views and opinions of authors expressed herein do not necessarily state or reflect those of the United States Government or any agency thereof. 


\section{DISCLAIMER}

Portions of this document may be illegible electronic image products. Images are produced from the best available original document. 


\title{
Experiment Close Out of Lysimeter Field Testing of Low-Level Radioactive Waste Forms
}

\author{
John W. McConnell, Jr., Robert D. Rogers, Julie D. Jastrow," \\ Steven R. Cline, ${ }^{b}$ Terry M. Sullivan, ${ }^{c}$ and Phil Reed ${ }^{d}$ \\ Idaho National Engineering Laboratory \\ P.O. Box 1625, Idaho Falls, Idaho 83415
}

\section{ABSTRACT}

The Field Lysimeter Investigations: Low-Level Waste Data Base Development Program is obtaining information on the performance of radioactive waste forms (WFs). These experiments were recently shut down and the contents of the lysimeters have been examined in accordance with a detailed waste form and soil sampling plan. Ion-exchange resins from a commercial nuclear power station were solidified into waste forms using portland cement and vinyl ester-styrene. These waste forms were tested to (a) obtain information on performance of waste forms in typical disposal environments, (b) compare field results with bench leach studies, ${ }^{\circ}$ develop a low-level waste data base for use in performance assessment source term calculations, and (d) apply the DUST computer code to compare predicted cumulative release to actual field data. The program, funded by the Nuclear Regulatory Commission (NRC), includes observed radionuclide releases from waste forms in field lysimeters at two test sites over 10 years of successful operation. The purpose of this paper is to present the results of the examination of waste forms and soils of the two lysimeter arrays after shut down. During this examination, the waste forms were characterized after removal from the lysimeters and the results compared to the fundings of the original characterizations. Vertical soil cores were taken from the soil columns and analyzed with radiochemistry to define movement of radionuclides in the soils after release from the waste forms. A comparison is made of the DUST code predictions of releases using recently developed partition coefficients to actual radionuclide movement through the soil columns as determined from these core analyses. This paper discusses soil and waste form sampling in which vertical cores were removed from the lysimeter soil columns for laboratory characterization. Those samples will be analyzed for radionuclide movement from the waste forms and through the soil columns. Further analysis of soil cores taken to define the observed upward migration of radionuclides in one lysimeter is also presented.

\section{INTRODUCTION}

a. Argonne National Laboratory, Argonne, IL 60439.

b. Oak Ridge National Laboratory, Oak Ridge, TN 37831.

c. Brookhaven National Laboratory, Upton, NY 11973.

d. U.S. Nuclear Regulatory Commission, Rockville, MD 20852 


\section{INTRODUCTION}

This paper presents the experimental results of the examination of the waste forms and soils from the two field lysimeter arrays. While results of this program have been presented at previous WM meetings, this paper completes the study, and includes discussion of the final results of the examination of the soils and waste forms from the lysimeters after experiment shutdown and exhumation. During the examination, the waste forms were characterized, after removal from the lysimeter, and these results are compared to the original characterizations, thus providing the basis for a material balance of the radionuclides present. Vertical soil cores were taken from the soil columns and were analyzed by radio chemistry to determine movement of radionuclides after release from the waste forms. A comparison is made of the DUST code predicted releases to releases previously determined and reported from the lysimeter leachate analyses. That comparison uses distribution coefficients $\left(K_{d}\right)$ recently obtained from laboratory analysis of the lysimeter soils and sand.

The U.S. Nuclear Regulatory Commission (NRC) has enacted regulations that link LLW acceptance criteria to the long-term satisfactory performance of the waste. Under Code of Federal Regulations (CFR) 10, Part 61, "Licensing Requirements for Land Disposal of Radioactive Wastes" (1), commercially generated LLW is classified as Class A, B, C, or Greater Than Class C. Wastes classified as either Class $B$ or Class $C$ must be stabilized for a minimum of 300 years. To verify the 300 -year stability of waste forms, the NRC originally specified the use of short-term standardized tests with the intention that such tests would provide information relevant to near-surface disposal performance objectives. Those tests were initially published in the NRC Branch "Technical Position on Waste Form" (2), and have been revised in Revision 1 of the Technical Position (3). Of critical importance in the disposal of LLW is the need for a detailed understanding of the waste form behavior. That is necessary because the radionuclide source is the driving force behind the site performance. A major requirement in any site licensing is also the site performance assessment, which is used to evaluate whether or not a proposed disposal site will meet performance objectives. The objective of the Field Lysimeter Investigations: Low-Level Waste Data Base Development Program is to compare the results of short-term laboratory leach testing, performed earlier by the INEEL, with actual leaching in the field. This program, funded by the NRC, has been operating lysimeters for over 10 years to obtain information on the performance of radioactive waste forms in a disposal environment and to investigate waste form stability per requirements of $10 \mathrm{CFR} 61$. The experiment measured the releases of radionuclides and chemical species from the waste forms and the subsequent transport through soil columns to sampling locations within the lysimeters. The recent radiochemical analysis of the waste forms and soil samples has added significantly to the information base concerning movement of radionuclides through the soils of these Isyimeters. This study was developed to field test waste forms composed of solidified ion-exchange resin materials from EPICOR-II prefilters used in the cleanup of Unit 2 of the Three Mile Island Nuclear Power Station (4). Wastes used in the study are significant because they are nuclear grade ion-exchange media with high loadings of radionuclides.

a. References herein to any specific commercial product, process, or service by trade name, trademark, manufacturer, or otherwise, does not necessarily constitute or imply its endorsement, recommendations, or favoring by the United States Government or any agency thereof. 


\section{EXPERIMENT DESCRIPTION}

Wastes used in the experiment include a mixture of highly loaded, nuclear-grade, synthetic, organic ion-exchange resins from EPICOR-II prefilter PF-7 and a mixture of organic-exchange resins and an inorganic zeolite from prefilter PF-24. Solidification agents employed to produce the $4.8 \times 7.6-\mathrm{cm}$ cylindrical waste forms used in the study were portland type I-II cement and DOW vinyl ester-styrene (VES). Seven of the waste forms were stacked end-to-end and inserted into each lysimeter to provide a 1-L volume. The PF-7 waste contained $89 \%$ of the radionuclide activity as Cs-137, while PF-24 contained 94\% Cs-137. The PF-7 waste also contained 5\% Sr-90, and PF-24 contained 1\% Sr-90. There were also measurable amounts of Cs-134, Co-60, and Sb-125 found in those wastes. Details on waste form descriptions, formulations, and initial waste form characterization are given in References (4) and (5). A listing of lysimeter waste form and fill material types are given in Reference (6).

Ten lysimeters were used in this study: five at Oak Ridge National Laboratory (ORNL) in Tennessee and five at Argonne National Laboratory-East (ANL-E) in Illinois. The lysimeters were designed to be self-contained units that will be disposed at the termination of the study. Each lysimeter consisted of a $0.91 \times 3.12-\mathrm{m}$ right-circular cylinder divided into an upper compartment that contained fill material, waste forms, and instrumentation, and a lower compartment for collecting leachate (Fig. 1). Four lysimeters at each site were filled with soil; a fifth, used as a control, was filled with inert silica oxide sand. The lysimeters at ANL-E contain soil indigenous to the site, while the ORNL lysimeters contained soil taken from Savannah River Laboratory in South Carolina. The soil columns were $2.21 \mathrm{~m}$ deep.

Instrumentation in each lysimeter included moisture cup soil-water samplers and soil moisture/ temperature probes. The probes, located at three elevations, were connected to an onsite data acquisition system (DAS), which also collected data from a field meteorological station located at each site. Porous cup soil-water samplers and the leachate collection compartment comprised the water sampling components of each lysimeter (Fig. 1). Incoming precipitation moved downward through the soil column to the waste form, then on to cups 3 and 1 , and finally to the leachate collector at the bottom. Radial movement of waste form releases were detected in cups 5,4 , and 2 , while vertical release was observed by cups 3 and 1 . Samples of moisture were withdrawn from the cups and the collector. Lysimeter design, installation, instrumentation, and data acquisition are explained in Reference (6). Monitoring of the lysimeters at ANL-E and ORNL began with the collection of liquid samples in September 1985 and continued through shutdown in October 1995 with sample collection on approximately a quarterly basis. Samples of liquids were taken from locations nearest the waste forms and from the leachate collectors to track the migration of radionuclides, primarily Sr-90 and Cs-137. Each month, data stored on a cassette tape in the DAS were retrieved and translated into an IBM PC-compatible disk file. 




Fig. 1. Isometric drawing showing the lysimeter experiment, cores, and samples. 


\title{
RESULTS AND DISCUSSION
}

\author{
Weather and Soil Data
}

Precipitation, air temperature, wind speed, and relative humidity were recorded continuously by the ANL-E and ORNL DAS during the experiment. The cumulative volume of leachate from the lysimeters since the initiation of field work, and examples of the lysimeter soil temperature and moisture data from ANL-E and ORNL sites are found in Reference (7). Data recorded in FY-95 indicate that the lysimeter soil columns at both sites have remained moist during the last reporting period.

\section{Radionuclide Data from Leachates}

Data show that not all nuclides consistently appeared in the water obtained from the moisture cups or the leachate collectors. The nuclide that appeared with the most regularity at both sites was Sr-90. Table I contains a comparison of the percent of inventory release of Sr-90 and Cs-137 found in the moisture cups and leachate water. Gamma-producing nuclide releases from the waste forms to the cups occurred with regularity at both sites (Table I). However, only waste forms at ORNL released detectable amounts of Cs- 137 to the leachate collectors (Table I).

Table I. Percent of Sr-90 and Cs-137 total inventories released per lysimeter to moisture cups and leachate water through July $1995(7)$.

\begin{tabular}{|c|c|c|c|c|c|c|c|c|c|}
\hline \multirow{3}{*}{$\begin{array}{c}\text { Lysimeter } \\
\text { Number }\end{array}$} & \multirow{3}{*}{$\begin{array}{c}\text { Solidifi- } \\
\text { cation } \\
\text { Agent }\end{array}$} & \multicolumn{4}{|c|}{$\begin{array}{l}\text { Percent Total Inventory } \\
\text { Sr-90 }\end{array}$} & \multicolumn{4}{|c|}{$\begin{array}{c}\text { Percent Total Inventory } \\
\text { Cs-137 }\end{array}$} \\
\hline & & \multicolumn{2}{|c|}{$\begin{array}{c}\text { Moisture } \\
\text { Cups }\end{array}$} & \multicolumn{2}{|c|}{$\begin{array}{l}\text { Leachate } \\
\text { Collectors }\end{array}$} & \multicolumn{2}{|c|}{$\begin{array}{c}\text { Moisture } \\
\text { Cups }\end{array}$} & \multicolumn{2}{|c|}{$\begin{array}{l}\text { Leachate } \\
\text { Collectors }\end{array}$} \\
\hline & & ANL-E & ORNL & ANL-E & ORNL & ANL-E & ORNL & ANL-E & ORNL \\
\hline 1 & Cement & $1.4 \mathrm{E}-4$ & $9.7 \mathrm{E}-4$ & $0.4 E-4$ & $0.4 \mathrm{E}-4$ & - & - & - & $1.7 \mathrm{E}-6$ \\
\hline 2 & Cement & $4.4 \mathrm{E}-4$ & $7.8 \mathrm{E}-4$ & $0.7 \mathrm{E}-4$ & $0.7 \mathrm{E}-4$ & $0.2 \mathrm{E}-6$ & - & - & $0.1 E-6$ \\
\hline 3 & VES & $69.4 E-4$ & $13.0 \mathrm{E}-4$ & $16.1 \mathrm{E}-4$ & $16.1 \mathrm{E}-4$ & - & - & - & $1.4 E-6$ \\
\hline 4 & VES & 14.7E-4 & $3.3 E-4$ & $2.2 \mathrm{E}-4$ & $2.2 \mathrm{E}-4$ & - & - & - & $0.4 \mathrm{E}-6$ \\
\hline 5 & Cement & $2.7 \mathrm{E}-4$ & $8.8 E-4$ & $225.0 \mathrm{E}-4$ & $1,812.0 \mathrm{E}-4$ & $71.9 \mathrm{E}-6$ & 1.3E-6 & - & $434.0 \mathrm{E}-6$ \\
\hline
\end{tabular}

\section{Lysimeter Waste Form and Soil Core Sampling}

The primary objective of the recently completed waste form and soil sampling was to obtain the waste forms from all of the five lysimeters at each site in cylindrical cores. Secondary objectives were to extract soil cores, soil microbial samples, selected moisture cups, filter fabric samples, and filter support stone samples. Seven soil cores were to be taken per lysimeter, one for the waste form and six for soils. Four soil grab samples, one filter cloth cut sample, and one filter support rock grab sample per lysimeter were planned. Moisture cup numbers 1 and 3 from each lysimeter also were to be collected. All waste form cores were successfully taken at both sites and were transported to the INEEL for detailed examination. Nearly all soil cores were taken at ANL-E, while only cores number 1 and sample 1 of cores number 2 
were taken at ORNL. Samples of filter cloth, filter support rock, and moisture cups 1 and 3 were obtained only from the ANL-E control lysimeter.

A diagram of the sample locations and sizes is shown in Fig. 1, and Table II lists the cores and samples. The waste form cores (number 2) were $7.5 \mathrm{~cm}$ in diameter and $58.5 \mathrm{~cm}$ long and extended from horizon 2 to 3 . That length contained all seven waste form samples. The soil cores and microbial soil samples were $3.3 \mathrm{~cm}$ in diameter and various lengths. All were taken with coring tools made up of multiple $25-\mathrm{cm}$ long segments. The microbial soil samples were also taken with the $3.3-\mathrm{cm}$ diameter tool using one segment. All cores were contained in plastic, cylindrical-core tool liners that were closed with plastic end caps. Radial and vertical position of the coring tools was controlled during coring operations by use of special guide plates and bushings. The coring tools and tips were specifically designed for this task by Art's Manufacturing and Supply of American Falls, Idaho. The INEEL designed the special guide system.

Radiochemical characterizations, including full-length gamma scanning of each seven-sample waste form and radiochemical analysis of segments of selected samples from each waste form, were designed to provide information on the remaining waste form radionuclide inventory. Waste form physical condition was determined by visual examination, weighing, and compressive testing. Soil cores were radiochemically analyzed for nuclide content, as were the filter cloth, filter support stone, and moisture cup. These data can then be used to determine radionuclide material balance within each lysimeter, radionuclide pathways through the soil columns, and radionuclide holdup factors of the various components of each lysimeter system. Other soil samples are being examined for microbial activity, which may then be related to waste form physical condition indirectly or more directly by microbial examination of waste form surface swipe samples. The analysis of microbial samples has not been completed but viable growth has been observed in all waste form surface swipes and soil samples.

\section{Waste Form Characterization}

The WFs, comprised of 7 samples each $5-\mathrm{cm}$ in diameter by $7.5-\mathrm{cm}$ long, were examined in detail to determine the effects of over 10 years of disposal site burial. Full length gamma scanning was performed on the WF cores before the plastic liners used to collect them were opened. All WFs showed reasonably uniform of doses from sample to sample and good agreement in magnitude of dose between like WFs. One WF exhibited a significant dose decrease at the lower end. Later examination of the core (ANL3) found that the bottom sample was missing. It was later found, still in the soil column at ANL-E. This set of measurements allowed confirmation that the individual sample inventories were within acceptable limits.

Photographs were taken of the WF cores after they had been opened and the samples exposed. Examination indicated that a majority of the samples were in good to excellent condition. There was some damage (cracks and edge chips) caused during installation in 1985, as indicated by soiled fractures. In other cases the fracture surfaces were clean, indicating damage caused during coring operations. Most samples had soil adhering to all surfaces. Those from ANL-E were estimated to have about twice as much adhering soil. The ANL-E soil also adhered more tenaciously.

All WFs were weighed and those weights were compared to the original as-cast weights. In general, the cement samples, which had more adhering soil, weighed more after field test. The VES samples weighed less after field test. It is thought that all samples lost weight due to dry-out during hot cell storage 
( 5 months) but the adhering soil caused the cement WFs to weigh more than as-cast. Microbial action could also have resulted in a weight loss but that process has not as yet been quantified by this work.

Three samples were selected from each WF and subjected to compressive testing. All samples exhibited excellent strength with exception of one cement sample loaded with organic/inorganic resins. That test piece failed at 472 psi apparently due to an unnoticed flaw. Those results are presented in Table III. The average compressive strengths when plotted against estimated self irradiation dose (listed in Table III) compare very closely with the results of aging tests given in Reference 9.

One sample was selected from each WF for radiochemical analysis. Those samples were sectioned, pulverized, homogenized, and 2 to $5 \mathrm{gm}$ subsamples were extracted. Those subsamples were analyzed for beta and gamma emitters with the results shown in Table IV. Cesium-137 and Strontium, the primary radionuclides present, will be the nuclides of discussion. Cesium 134 and Cobalt-60 were found only in trace amounts. The after-field-test WF inventories are compared to as-cast inventories in the table. The average release of $\mathrm{Cs}-137$ was $37 \%$ compared to the average release of Sr-90 ot $65 \%$. A majority of the WFs exhibited near average releases of both nuclides with the exception of the VES WFs of ANL3 and ANLA which showed releases of both nuclides significantly above the averages, Cs-137 at 61 and 50 percent and Sr-90 at 92 and 86 percent respectively. The ANL2 and ORNL2 with similar cement WFs exhibited releases of both nuclides in similar amounts. The WFs in ANL5 and ORNL1 also performed very much alike although ANL5 contained silica sand versus soil in ORNL1. It is interesting to note that these releases are considerably higher than the 4 to $9 \% \mathrm{Cs}$ and $\mathrm{Sr}$ releases resulting from the 90 day leach testing of similar WFs and reported in Reference 8.

\section{Soil Radiochemical Analysis}

Soil and sand samples were taken directly with coring tools and also as part of the WF cores. Each WF core held about $1.7-\mathrm{cm}$ thick shell along side the WFs and about $5-\mathrm{cm}$ of soil/sand in the lower tip. Table $\mathrm{V}$ lists the calculated total radionuclide content in the side and tip soils/sands of each core as well as the percent of WF as-cast inventory for both Cs-137 and Sr-90. While the percent of nuclide inventory retained in the $1.3-\mathrm{cm}$ thick by $54-\mathrm{cm}$ long cylindrical side soils/sands were significant, ranging from 0.4 to 8.5 percent for $\mathrm{Cs}-137$ and 0.1 to 10.3 percent for $\mathrm{Sr}-90$, the percent retained in the $5-\mathrm{cm}$ long by $5-\mathrm{cm}$ diameter core tip soils/sands was insignificant at 0.001 to 0.1 percent for Cs-137 and 0.002 to 0.4 percent for Sr-90. The highest percent Cs capture was in ANL3 while the highest percent Sr retention was in ANL1. The ANL soils retained more of both radionuclides than did the ORNL soils. It also appears that the WFs screened the soil/sand in the tips from downward moving nuclides compared to the soil/sand along side the WFs.

Detailed radiochemical analysis of the directly cored soil/sand resulted in data sets too extensive to present here, at $151 \mathrm{Cs}$ and $158 \mathrm{Sr}$ data points. However, those data will be used to plot isograms of specific activities for both nuclides for the ANL-E lysimeters. The limited results from ORNL cores \#1 and $\# 2$ make isograms of that data useless. The isograms of ANL-E data will be included in this paper when they are completed. Using those plots the nuclide inventory retained by the soil/sand columns will

be calculated. Rough estimates indicate that it is also significant but not large enough to provide for a complete material balance.

An examination of the data shows that there was radial dispersion Cs-137 in all the soil Lysimeters to $12.5-\mathrm{cm}$ radius and to $25-\mathrm{cm}$ radius in the sand lysimeter. That radial movement was seen from the top of 
the WFs to the bottom of the soil column in all but ANLI where none was detected near the top of the WF or bottom of the soil column. Similar but less extensive Sr-90 dispersion was also found. Soil units ANL1 and ANL4 contained that nuclide at $25-\mathrm{cm}$ radius from the top of the WF to the bottom of the soil column while in all others it was detected to $12.5-\mathrm{cm}$ radius.

The information from the \#1 soil cores at both sites shows that some upward movement of both nuclides occurred, that Cs-137 moved upward in larger concentrations than Sr-90, that ORNL had larger concentrations of both nuclides to higher elevations than did ANL-E, and that the ORNL and ANL-E soil and sand columns experienced hot spots at higher elevations. That is similar to what was observed in the ORNL5 lysimeter and thought to be the result of periodic WF flooding as discussed in Reference 12.

Other samples were analyzed for Cs-137 and Sr-90 content. those included Moisture cups \#1 and \#3, cup \#1 silica flour, filter cloth, and filter rock all taken from ANL5. The results of those analyses are shown in Table VI and include total activity of the whole component. Also included is amount of total inventory retained by the component. The percent of inventory retained is very small for all samples and will not be an effect in a material balance. However, those percentages also must be compared to the percentage of inventory that was measured in cup \#3 and the leachate collector in ANL5 and ORNL5. That can be done by comparing the values in Table I with those in Table VI. The cup \#3 retention of Sr90 was a factor of 45 less than the smallest lysimeter 5 cup measurement (in ANL5) while the rock and filter cloth retention of $\mathrm{Sr}-90$ were 124 times smaller than the smallest leachate collector measurement (in ANL5). Cup retention had no effect on sand or soil Sr-90 measurements but rock retention could have effected Sr-90 measurements of leachate in lysimeters ANL1, ANL2, ANLA, ORNL1, ORNL2, and ORNL4. Cup \#3 retention of Cs-137 in lysimeter 5 was 38 times larger than the smallest observed cup measurement (in ORNL5) and about the same as the largest (in ANL5). Rock retention of Cs-137 was 10 times the ORNL leachate measurement (no Cs -137 was measured at ANL-E). Both cup and rock retention of Cs-137 effected measurements in lysimeters 5 and probably in the soil lysimeters also. 
Table II. Core and other samples.

\begin{tabular}{|c|c|c|c|}
\hline Sample Designation & $\begin{array}{c}\text { Number of } \\
\text { Samples/Makeup }\end{array}$ & $\begin{array}{c}\text { Sample Length } \\
\text { (cm) }\end{array}$ & Planned Analysis \\
\hline Core number 1 & 8 & 12.5 & Radionuclide \\
\hline \multirow[t]{2}{*}{ Core number 2} & 1 & 54.5 & Radionuclide \\
\hline & 1 & 4.0 & Radionuclide \\
\hline \multirow{2}{*}{ Core number 3} & 4 & 12.5 & Radionuclide \\
\hline & 1 & 7.5 & Radionuclide \\
\hline \multirow[t]{2}{*}{ Core number 4} & 4 & 12.5 & Radionuclide \\
\hline & 1 & 7.5 & Radionuclide \\
\hline Core number 5 & 5 & 6.3 & Radionuclide \\
\hline \multirow[t]{2}{*}{ Core number 6} & 6 & 6.3 & Radionuclide \\
\hline & 1 & 7.5 & Radionuclide \\
\hline \multirow[t]{2}{*}{ Core number 7} & 3 & 12.5 & Radionuclide \\
\hline & 1 & 7.5 & Radionuclide \\
\hline Sample number 8 & Filter cloth & NA & Radionuclide \\
\hline Sample number 9 & Rock & NA & Radionuclide \\
\hline Core number 10 & Soil & 25 & Microbial \\
\hline Core number 11 & Soil & 25 & Microbial \\
\hline Core number 12 & Soil & 25 & Microbial \\
\hline Core number 13 & Soil & 25 & Microbial \\
\hline Sample number 14 & Soil & NA & Microbial \\
\hline Sample number 15 & Waste form swipes & NA & Microbial \\
\hline Sample number 16 & Moisture cup 3 & NA & Radionuclide \\
\hline Sample number 17 & Moisture cup 1 & NA & Radionuclide \\
\hline
\end{tabular}


Table III. Average compressive strengths of waste form samples by type.

\begin{tabular}{|c|c|c|c|c|c|}
\hline \multirow{2}{*}{ Sample Type ${ }^{*}$} & \multirow{2}{*}{$\begin{array}{l}\text { Lysimeter fill } \\
\text { Material }\end{array}$} & \multicolumn{3}{|c|}{ Average Compressive Strength (psi) } & \multirow{2}{*}{$\begin{array}{l}\text { Self Irradiation } \\
\text { Dose (Rad) }\end{array}$} \\
\hline & & ORNL & ANL-E & Averaged ${ }^{b}$ & \\
\hline $\mathrm{Cl}$ & Soil & $3039 \pm 1106$ & $4840 \pm 575$ & $3939 \pm 1263$ & $0.7 \times 10^{6}$ \\
\hline $\mathrm{C} 2$ & Soil & $4473 \pm 1011$ & $3564 \pm 1302$ & $4019 \pm 1155$ & $1.8 \times 10^{6}$ \\
\hline D1 & Soil & $3016 \pm 89$ & $2939 \pm 55$ & $2978 \pm 78$ & $1.3 \times 10^{6}$ \\
\hline D2 & Soil & $3189 \pm 235$ & $3418 \pm 181$ & $3303 \pm 226$ & $3.9 \times 10^{6}$ \\
\hline $\mathrm{Cl}$ & Sand & & $2343 \pm 2197$ & $3407 \pm 1686$ & $0.7 \times 10^{6}$ \\
\hline $\mathrm{C} 2$ & Sand & $5922 \pm 511$ & & $4653 \pm 1347$ & $1.8 \times 10^{6}$ \\
\hline
\end{tabular}

a) $\mathrm{C}=$ portland cement, $\mathrm{D}=$ vinyl ester styrene, $1=$ organic ion exchange resin; 2 = organic/inorganic ion exchange resin.

b) soil - averaged compressive strengths include data of soil from both sites sand - averaged compressive strengths include data from same sample type from both sand and soil. 
Table IV. Comparison of Cesium 137 and Strontium 90 inventories before and after field test.

\begin{tabular}{|c|c|c|c|c|c|c|c|c|}
\hline \multirow[t]{3}{*}{$\begin{array}{c}\text { Lysimeter } \\
\text { No. }\end{array}$} & \multicolumn{2}{|c|}{$\begin{array}{l}\text { Before Test Inventory }{ }^{4.9} \\
\left(10^{8} \mathrm{pCi}\right)\end{array}$} & \multicolumn{2}{|c|}{$\begin{array}{l}\text { After Test Inventory } \\
\left(10^{8} \mathrm{pCi}\right)\end{array}$} & \multicolumn{4}{|c|}{ Inventory Released by Waste Form } \\
\hline & \multirow[t]{2}{*}{ Cs-137 } & \multirow[t]{2}{*}{ Sr-90 } & \multirow[t]{2}{*}{ Cs-137 } & \multirow[t]{2}{*}{$\operatorname{Sr}-90$} & \multicolumn{2}{|c|}{ Cs- 137} & \multicolumn{2}{|c|}{$\mathrm{Sr}-90$} \\
\hline & & & & & $\left(10^{8} \mathrm{pCi}\right)$ & $(\%)$ & $\left(10^{8} \mathrm{pCi}\right)$ & (\%) \\
\hline ANL 1 & 2,300 & 139 & 1,650 & NA & 650 & 28 & - & - \\
\hline ANL 2 & 10,570 & 22 & 6,730 & 10.9 & 3,840 & 36 & 11.1 & 50 \\
\hline ANL 3 & 3,430 & 198 & 1,320 & 15.2 & 2,110 & 61 & 182.8 & 92 \\
\hline ANL 4 & 14,230 & 37 & 7,110 & 5.1 & 7,120 & 50 & 31.9 & 86 \\
\hline ANL 5 & 2,300 & 139 & 1,410 & 57.1 & 890 & 39 & 81.9 & 59 \\
\hline ORNL 1 & 2,300 & 139 & 1,440 & 56.9 & 860 & 37 & 82.1 & 59 \\
\hline ORNL 2 & 10,570 & 22 & 6,990 & 12.4 & 3,580 & 34 & 9.6 & 44 \\
\hline ORNL 3 & 3,430 & 198 & 2,640 & 50.5 & 790 & 23 & 147.5 & 74 \\
\hline ORNL 4 & 14,230 & 37 & 9,720 & 12.0 & 4,510 & 32 & 25.0 & 68 \\
\hline ORNL 5 & 10,570 & 22 & 7,440 & 10.6 & 3,130 & 30 & 11.4 & 52 \\
\hline & & & & & rage $\% \mathrm{Re}$ & $37 \pm$ & & 65 \\
\hline
\end{tabular}

NA - Data not usable 
Table V. Waste form core soil radionuclide contents and percent of inventory retained.

\begin{tabular}{|c|c|c|c|c|c|c|c|c|}
\hline \multirow{2}{*}{$\begin{array}{c}\text { Lysimeter } \\
\text { No. }\end{array}$} & \multicolumn{2}{|c|}{$\begin{array}{c}\text { Waste Form Core Side Soil } \\
\text { Radionuclide Content (10 }\end{array}$} & \multicolumn{2}{c|}{$\begin{array}{c}\text { Percent of Total Inventory } \\
\text { Retained by Core Side Soil (\%) }\end{array}$} & \multicolumn{2}{|c|}{$\begin{array}{c}\text { Waste Form Core Tip Soil } \\
\text { Radionuclide Content (10 pCi) }\end{array}$} & \multicolumn{2}{c|}{$\begin{array}{c}\text { Percent Inventory Retained } \\
\text { by Core Tip Soil (\%) }\end{array}$} \\
\cline { 2 - 9 } & Cs-137 & Sr-90 & Cs-137 & Sr-90 & Cs-137 & Sr-90 & Cs-137 & Sr-90 \\
\hline ANL 1 & 127 & 10.7 & 5.5 & 10.3 & 0.03 & 0.004 & 0.001 & 0.004 \\
\hline ANL 2 & 209 & 0.3 & 2.0 & 1.5 & 1.1 & 0.02 & 0.01 & 0.09 \\
\hline ANL 3 & 292 & 6.1 & 8.5 & 3.1 & 3.3 & 0.50 & 0.10 & 0.30 \\
\hline ANL 4 & 149 & 0.8 & 1.1 & 2.2 & 10.8 & 0.14 & 0.08 & 0.40 \\
\hline ANL 5 & 11 & 0.4 & 0.5 & 0.3 & 1.5 & 0.003 & 0.07 & 0.002 \\
\hline ORNL 1 & 68 & 4.8 & 3.0 & 3.4 & 2.0 & 0.07 & 0.09 & 0.05 \\
\hline ORNL 2 & 128 & 0.03 & 1.2 & 0.1 & 4.0 & 0.007 & 0.04 & 0.03 \\
\hline ORNL 3 & 152 & 3.3 & 4.4 & 1.7 & 3.6 & 0.78 & 0.10 & 0.40 \\
\hline ORNL 4 & 105 & 0.8 & 0.7 & 2.1 & 3.3 & 0.12 & 0.02 & 0.30 \\
\hline ORNL 5 & 39 & 0.02 & 0.4 & 0.1 & 3.2 & 0.004 & 0.03 & 0.02 \\
\hline
\end{tabular}


Table VI. Other samples radionuclide contents \& percent of total inventories retained.

\begin{tabular}{|c|c|c|c|c|}
\hline \multirow{2}{*}{ Sample Name \& Number } & \multicolumn{2}{|c|}{$\begin{array}{c}\text { Total Component } \\
\text { Activity (pCi) }\end{array}$} & \multicolumn{2}{c|}{$\begin{array}{c}\text { Amount of Total } \\
\text { Inventory Retained (\%) }\end{array}$} \\
\cline { 2 - 5 } & Cs-137 & Sr-90 & Cs-137 & $0.06 \mathrm{E}-4$ \\
\hline $\begin{array}{c}\text { Moisture Cup No. 3 } \\
\text { ANL 5-16 }\end{array}$ & 101,000 & 793 & $50 \mathrm{E}-6$ & $0.03 \mathrm{E}-4$ \\
\hline $\begin{array}{c}\text { Moisture Cup No. 1 } \\
\text { ANL 5-17 }\end{array}$ & 13,600 & 48 & $10 \mathrm{E}-6$ & $0.11 \mathrm{E}-4$ \\
\hline $\begin{array}{c}\text { Cup No. 1 Silica } \\
\text { ANL 5-18 }\end{array}$ & 355,00 & 1,547 & $160 \mathrm{E}-6$ & $0.05 \mathrm{E}-4$ \\
\hline $\begin{array}{c}\text { Filter Cloth } \\
\text { ANL 5-8 }\end{array}$ & 95,000 & 742 & $40 \mathrm{E}-6$ & $1.77 \mathrm{E}-4$ \\
\hline $\begin{array}{c}\text { Filter Rock } \\
\text { ANL 5-9 }\end{array}$ & $9,840,000$ & 24,549 & $4300 \mathrm{E}-6$ & \\
\hline
\end{tabular}

a) These samples were corrected to dry weight 
Table VI. Linear $K_{d}$ values for cesium and strontium in lysimeter materials.

\begin{tabular}{|c|c|c|}
\hline Material & $\begin{array}{c}\text { Cesium } \mathrm{K}_{d} \\
\left(\mathrm{~cm}^{3} / \mathrm{g}\right)\end{array}$ & $\begin{array}{c}\text { Strontium } \mathrm{K}_{d} \\
\left(\mathrm{~cm}^{3} / \mathrm{g}\right)\end{array}$ \\
\hline ANL-E soil & 390 & 81 \\
ORNL soil & 37 & $20-40$ \\
ANL-E sand & 55 & 6.4 \\
ORNL sand & 40 & 6.3 \\
\hline
\end{tabular}

\section{SOURCE TERM MODELING OF LYSIMETER RELEASES}

The Disposal Unit Source Term (DUST) code (10) has been used to model the release of the radionuclides Cs-137 and $\mathrm{Sr}-90$ from the lysimeter waste forms. DUST is a one-dimensional code that accounts for container performance and waste form leaching (including diffusion-controlled release). Transport can be modeled through finite differences or by a multi-cell mixing cascade approach. The finite difference method was used in the simulations reported in this paper because it is more general than the mixing cell approach and permits modeling of dispersive transport. Use of these data in the DUST code was examined in detail in a paper presented at WM ' 93 (11) and has been presented more recently in References (7) and (12). Releases from the WFs of the sand filled lysimeters were examined in those references and compared to the measured data from leachate collectors.

The releases of Cs-137 and Sr-90 from portland type I-II cement located in the inert, sand-filled lysimeters 5 at ORNL and ANL-E were chosen because releases from other lysimeters were substantially lower; therefore, the data were not yet sufficient to model. At ANL-E, lysimeter 5 contained resin waste from PF-7 solidified in portland type I-II cement; at ORNL, lysimeter 5 contained resin waste from PF-24, which was also solidified in cement (Table I). Diffusion coefficient values measured in laboratory testing of these waste forms were $9.6 \mathrm{E}-10 \mathrm{~cm}^{2} / \mathrm{s}$ for $\mathrm{Sr}-90$ in portland cement and $6.0 \mathrm{E}-10 \mathrm{~cm}^{2} / \mathrm{s}$ for $\mathrm{Cs}-137$ in portland cement (13). The Darcy velocities ranged from $2.96 \mathrm{E}-6 \mathrm{~cm} / \mathrm{s}$ at ANL-E to $4.3 \mathrm{E}-6 \mathrm{~cm} / \mathrm{s}$ at ORNL (7). The soil bulk density values were $1.55 \mathrm{~g} / \mathrm{cm}^{3}$ at ANL-E and $1.60 \mathrm{~g} / \mathrm{cm}^{3}$ at ORNL (6). Moisture content values were found in Reference (7). In lysimeter 5 at both sites, the average moisture content was calculated to be $21 \%$. The partition or distribution coefficients were measured for Sr-90 and Cs-137 and are presented in Table VII (12). The dispersion coefficients have not been measured; therefore, they were estimated based on data in References (14) and (15) and by fitting the model predictions to the data. The cumulative activity collected in the lysimeter leachate water over the first 10 years of operation of the experiment, which was used to make comparisons to the DUST code predictions, represented cumulative fractional releases of about 0.0018 and 0.00023 of the $\mathrm{Sr}-90$ in lysimeter 5 at ORNL and ANL-E, respectively (Table I). The "best-fit" parameters for four different waste form release and nuclide transport models for $\mathrm{Sr}-90$ are displayed in Table VIII.

The three waste form release models all limit the total 10-year release from the waste form to about $10^{7} \mathrm{pCi}$, which is two orders of magnitude less than the release predicted on the base case parameters $\left(\mathrm{D}_{\mathrm{w}}\right.$ $\left.=9.6 \mathrm{E}-10 \mathrm{~cm}^{2} / \mathrm{s}\right)$. The best-fit diffusion coefficient was four orders of magnitude below the laboratorymeasured value. This low release rate is needed to match the data because of the relatively fast transport time that occurs when using the base case $K_{d}$ values. The best-fit transport parameter, $K_{d}=36$, is about the same as the laboratory-measured value of 37 and is much larger than the best-fit value found 
previously based on 8 years of data $\left(\mathrm{K}_{d}=24\right)$. After collecting the additional 2 years of data, it became clear that the previous best fit was too low. Fig. 2 (top) displays the predicted cumulative release of the four different scenarios and compares them to the measured data. All of them predict the cumulative release over 10 years to within $20 \%$ of the measured value. This is the result of the fitting procedure used to select the appropriate release parameters. The transport model curve does not compare well to the other curves.

The "best-fit" parameters for release and transport of Sr-90 in ANL-E lysimeter 5 for each of the alternative models are found in Table VI. The best-fit parameters differ from those found at ORNL lysimeter 5. The waste form diffusion coefficient and fractional release rate are lower than at ORNL. The ANL-E waste form best-fit diffusion coefficient, $1 \mathrm{E}-15 \mathrm{~cm}^{2} / \mathrm{s}$, is a factor of 50 lower than the best-fit value found for the ORNL data and almost six orders of magnitude lower than the laboratory-measured value. The solubility limit is slightly higher than found at ORNL because of the lower water flow rates found at ANL-E. The $K_{d}$ of 36 is within the range of the laboratory-measured partition coefficient. In Fig. 2 (bottom), the cumulative release based on the solubility limited release model tracks the measured value the best. The uniform and diffusion-controlled waste form release models also follow the trends in the measured data reasonably well. The high $\mathrm{K}_{d}$ model shows a much different shaped curve than the data or any of the other models.

Table VIII. Best-fit parameters for release of Sr-90 from lysimeters 5 at ORNL and ANL-E.

\begin{tabular}{|l|l|c|c|}
\hline \multicolumn{1}{|c|}{ Model } & \multicolumn{1}{|c|}{ Parameter } & ORNL & ANL-E \\
\hline Diffusion-controlled & Waste form diffusion coefficient $\left(\mathrm{cm}^{2} / \mathrm{s}\right)$ & $\mathrm{D}_{w}=5 \mathrm{E}-14$ & $\mathrm{D}_{\mathrm{wf}}=1 \mathrm{E}-15$ \\
release & & $4 \mathrm{E}-4$ & $1.3 \mathrm{E}-4$ \\
Uniform release & Uniform fractional release rate $\left(\mathrm{yr}^{-1}\right)$ & 1,260 & 1,680 \\
Solubility limited & Solubility limit $(\mathrm{pCi} / \mathrm{L})$ & $\mathrm{K}_{\mathrm{d}}=36$ & $\mathrm{~K}_{\mathrm{d}}=36$ \\
Transport limited & Partition coefficient $\left(\mathrm{cm}^{3} / \mathrm{g}\right)$ & Disp $=7.5$ & Disp $=8$ \\
& Dispersion coefficient $(\mathrm{cm})$ & \\
\hline
\end{tabular}





Fig. 2. Comparison of measured and DUST-predicted cumulative Sr-90 released. 


\section{CONCLUSIONS}

The radionuclide that has appeared with most regularity in the leachate at both sites is $\mathrm{Sr}-90$, although Cs-137 was observed regularly in the leachate of all ORNL lysimeters.

WF examination showed them to be in good to excellent condition with compressive strengths aligning with aging data according to amount of self irradiation dose.

The average release of Cs-137 from the 10 waste forms was $37 \%$ of WF inventory while the average release of $\mathrm{Sr}-90$ was $65 \%$. These releases are considerably higher than the 90 day leach test results of between 4 and $9 \%$ for both those radionuclides.

The soils and sand taken from the WF cores adjacent to the WFs contained from 0.4 to $8.5 \%$ of the Cs-137 WF inventory and from 0.1 to $10.3 \%$ of the Sr-90 WF inventory. The ANL-E soil retained more of both nuclides than did ORNL soil.

Soil core sample data indicate that radionuclides moved radially away from the WFs in all ANL-E lysimeters. Cs-137 dispersed further than did Sr-90. Upward movement was also found in all lysimeters with $\mathrm{Cs}-137$ in larger concentrations than Sr-90.

The retention of Cs- 137 by The moisture cups affected the measurements. Filter rock retention of both $\mathrm{Cs}-137$ and $\mathrm{Sr}-90$ affected the measurement of those nuclides in the leachate. These retentions must be included in any modeling effort.

DUST-predicted cumulative releases of Sr-90 from both ORNL and ANL-E lysimeters 5, which were plotted over 10 years of data collection, show a reasonable fit to the field data. The accuracy of the DUST modeling study was improved by use of the waste form releases and release patterns to better model the radionuclide movement in the lysimeters.

Data provided by these lysimeter experiments have been shown to be useful in computing many parameters used as input to performance assessment codes. The utility of this reliable source of data will be enhanced by application of radionuclide movement data from soil sampling to source term models such as DUST.

\section{ACKNOWLEDGMENTS}

This work was supported by the U.S. Nuclear Regulatory Commission, Office of Nuclear Regulatory Research, under U.S. Department of Energy Idaho Operations Office Contract DE-AC07-94ID13223. Dr. P. R. Reed is the NRC RES Program Manager of this work.

\section{REFERENCES}

1. CODE OF FEDERAL REGULATIONS, 10 CFR 61, "Licensing Requirements for Land Disposal of Radioactive Wastes," Office of the Federal Register (1982). 
2. U.S. NUCLEAR REGULATORY COMMISSION, "Technical Position on Waste Form, " Low-Level Waste Management Branch, Washington, DC (1983).

3. U.S. NUCLEAR REGULATORY COMMISSION, "Technical Position on Waste Form," Revision 1, Low-Level Waste Management Branch, Washington, DC (1991).

4. R. M. NEILSON and J. W. MCCONNELL, JR., "Solidification of EPICOR-II Resin Waste Forms," GEND-INF-055 (1984).

5. R. M. NEILSON, JR. and J. W. MCCONNELL, JR., "EPICOR-II Resin Waste Form Testing," NUREG/CR-4637, EGG-2457 (1986).

6. R. D. ROGERS, J. W. MCCONNELL, JR., E. C. DAVIS, and M. W. FINDLEY, "Field Testing of Waste Forms Containing EPICOR-II Ion Exchange Resins Using Lysimeter," NUREG/CR-4498 (1986).

7. J. W. MCCONNELL, JR., R. D. ROGERS, J. D. JASTROW, W. E. SANFORD, I. L. LARSEN and T. M. SULLIVAN, "Annual Report of the Lysimeter Field Investigations: Low-Level Waste Data Base Development Program for Fiscal Year 1995," NUREG/CR-5229, Vol. 8 (1996).

8. R. D. ROGERS, J. W. MCCONNELL, JR., E. C. DAVIS, and J. D. JASTROW, "Annual Report of the TMI-2 EPICOR-II Resin/Liner Investigation: Low-Level Waste Data Base Development Program for Fiscal Year 1988," NUREG/CR-5229, Vol. 1 (1988).

9. J. W. MCCONNELL, JR., R. M. NEILSON, JR., "The Effects of Aging on Compression Strength of Low-Level Radioactive Waste Forms Samples," NUREG/CR-6392 (1996).

10. T. M. SULLIVAN, "Disposal Unit Source Term (DUST) Data Input Guide," NUREG/CR-6041, BNL-NUREG-52295 (1993).

11. T. M. SULLIVAN, J. W. McCONNELL, JR., R. D. ROGERS, and I. T. FITZGERALD, "Modeling of Field Lysimeter Release Data Using the Computer Code DUST, " Waste Management ' 93 Proceedings of the Symposia on Waste Management, Tucson, AZ, February 28 to March 4, 1993, Vol. 1, pp. 781-5.

12. J. W. MCCONNELL, JR. R. D. ROGERS, J.D. JASTROW, W. E. SANFORD, S. R. CLINE, T. M. SULLIVAN, M. FUHRMANN, and P. R. REED, "Results after Ten Years of Field Testing Low-Level Radioactive Waste Forms Using Lysimeters," Waste Management "97 Proceedings of the Symposia on Waste Management, Tucson, AZ, March 2-6, 1997.

13. J. W. MCCONNELL, JR., Information presented at the NRC Workshop on Performance Assessment, Washington, D.C. (June 2-5, 1992).

14. D. ISHERWOOD, "Geoscience Data Base Handbook for Modeling a Nuclear waste Repository," NUREG/CR-0912, Vol. 1 (1981). 
15. R. A. FREEZE AND J. A. CHERRY, "Groundwater," Chapter 9, pp. 430-432, Prentice-Hall, Inc., Englewood Cliffs, NJ (1979). 